\title{
Carving the Future of Nature Ecotourism in Indonesia: Case of Taman Wisata Alam Telogo Warno Telogo Pengilon
}

\author{
Tri Satyatama $^{1 *}$, Lies Rahayu Wijayanti Faida ${ }^{2}$, Ris Hadi Purwanto ${ }^{2}$, Chafid Fandeli ${ }^{2}$ \\ ${ }^{1}$ Graduate Program of Forestry Science, Faculty of Forestry, Gadjah Mada University, Jl. Agro No. 1, Bulaksumur, \\ Sleman, Indonesia 55281 \\ ${ }^{2}$ Department of Forest Resource Conservation, Faculty of Forestry, Gadjah Mada University, Jl. Agro No. 1, Bulaksumur, \\ Sleman, Indonesia 55281
}

Received December 31, 2019/Accepted March 5, 2020

\begin{abstract}
Indonesia has potential ecotourism spots that are needed to be utilized as well as to increase the value of forest benefits from the aspect of environmental services. The utilization must be carried out carefully while maintaining the function of the area. However, there are constraints in managing natural tourism in conservation areas according to the concept of sustainable tourism. This study adopts the basic concept of evaluating the management of natural tourism as stipulated in the Regulation of The Ministry of Tourism Number 14 of 2016 on Guidelines for Sustainable Tourism Destination. The purpose of this study is to evaluate the performance of sustainable nature tourism management applied in Taman Wisata Alam Telogo Warno Telogo Pengilon (TWA TWTP). The data were collected under three main techniques: a direct interview with related stakeholders, field measurement and direct observation, and grey literature. The management forms a partnership between the Balai Konservasi Sumber Daya Alam Jawa Tengah (Central Java Natural Resources Conservation Office; BKSDA) and PT. Alam Indah Bonbin Lestari (AIBBL) as the holder of Izin Usaha Penyediaan Sarana Wisata Alam (Business License for the Provision of Nature Tourism Facilities; IUPSWA). The results showed improvement in the management of TWA TWTP. However, several issues that require immediate improvement remain. In general, all of the aspects are categorized into four scopes: (1) management of effective sustainable tourism destination, (2) the optimization of economic benefits for local communities, (3) the optimization of cultural preservation for the communities and visitors, and (4) environmental conservation.
\end{abstract}

Keywords: conservation, cultural preservation, local community, sustainable tourism, Telogo Warno Telogo Pengilon

*Correspondence author, email: satdco@yahoo.com

\section{Introduction}

Tourism is an industry that shows extraordinary growth throughout the world (UNWTO, 2018). New attractions, both natural and man-based, are increasingly popping up and competing for as many visitors as possible. The number of people taking part in various outdoor activities (in the form of ecotourism or nature-based tourism) is increasing. In the period 2010-2017, there has been an increase in tourist activity globally, as indicated by the increasing number of tourists (UNWTO, 2018). In Indonesia, the number of domestic tourist trips in 2018 grew by $12.37 \%$ compared to the previous year(BPS, 2019).

Although tourism brings significant economic benefits, mass tourism, if it is carried out without regard to the concept of sustainable tourism, will cause negative impacts, especially on the socio-cultural aspects and environmental damage (Kiper, 2013; Fandeli \& Muhammad, 2019). For example, an analysis of the development of ecotourism in
Pingdingshan, China, shows that the carrying capacity of the ecotourism environment has been overloaded due to the ignorance of the tour operator to the concept of sustainable ecotourism management (Zhao \& Jiao, 2019). Therefore, although tourism has been proved as a significant economic generator, the level of visits to sensitive areas needs to be limited (Gössling, 1999). Among the many definitions that are still being debated, ecotourism, according to CeballosLascuráin (1996), is a travel tour to natural places that are relatively undisturbed, intending to study, admire and enjoy the scenery, plants, animals, and cultural aspects found in these places. Ecotourism is a form of tourism activity in protected areas that are realized to be able to provide economic benefits (Honey, 1999), even recognized as a sector that is developing very rapidly in the tourism industry (Das \& Chatterjee, 2015; Mollet, 2016). Ecotourism can satisfy the desire of visitors to get to know new ecosystems, participate in efforts to conserve natural resources, as well as get to know 
the culture of local communities (Balmford et al., 2009). Balmford's opinion is in line with the definition outlined by the International Ecotourism Society (TIES). TIES defines ecotourism as a tour of the region that is still natural by (a) maintaining environmental sustainability, (b) maintaining the welfare of local communities, and (c) involving interpretation and education activities (TIES, 2019). Therefore, the management of ecotourism activities needs to be interpreted as nature-based tourism activities, environmentally educated, and managed sustainably (Blamey, 2001). This requirement means that ecotourism management still needs to hold the principle of responsible ecotourism in the aspect of "minimizing the environmental impact" (Hetzer, 1965; Honey, 1999; Kiper, 2013).

On the other hand, Indonesia has potential forest areas that can be used as a place for tourism activities. Some of these areas are managed by the Ministry of Environment and Forestry (KLHK) in the form of national parks (54 locations) and nature recreation parks (132 locations). Ecotourism spots in the areas need to be utilized as well as possible to increase the value of forest benefits (monetary value) from the aspect of environmental services while maintaining the function of the area.

Managing natural tourism in conservation areas according to the concept of sustainable tourism (Kiper, 2013) is not easy considering the ecotourism demands a unified and integrated system of management protection of natural resources. Constraints in the form of external pressure, limited human resource capacity, limited funds and infrastructure, weak coordination, and weak command support in the form of policy are problems that are often encountered at the implementation level (MFP-WWF, 2006). Therefore, the performance of nature tourism management in Indonesia needs serious attention. The management performance referred to in this paper is a management effort that accommodates aspects of the ecosystem sustainability of natural tourism locations (Rosalino \& Grilo, 2011), the interests of local communities (Kline, 2001), education (Balmford et al., 2009), excellent service for visitors, and economic benefits (Honey, 1999).

This research takes an example of the case of the management of nature tourism in the Taman Wisata Alam (Nature Recreation Park; TWA) Telogo Warno Telogo Pengilon (TWTP). Taman Wisata Alam Telogo Warno Telogo Pengilon is a main Non-Tax State Revenue (Pendapatan Negara Bukan Pajak/PNBP) contributor amongst five nature recreation parks managed by Balai Konservasi Sumber Daya Alam Jawa Tengah (Central Java Natural Resources Conservation Office; BKSDA Jawa Tengah). The financial contribution from this area reaches up to more than IDR2.8 billion in 2018 and IDR3.2 billion in 2019, while the closest competitor (TWA Grojogan Sewu) contributed about IDR2.5 billion and IDR2.3 billion at the same years. In fact, BKSDA Jawa Tengah is the most significant PNBP contributor. BKSDA Jawa Tengah is the largest contributor to environmental services PNBP among other regular BKSDA at KLHK in the year 2018. In this TWA TWTP, nature tourism management is carried out in the form of a partnership between the BKSDA Jawa Tengah and PT. Alam
Indah Bonbin Lestari (AIBBL) as the holder of Izin Usaha Penyediaan Sarana Wisata Alam (Business License for the Provision of Nature Tourism Facilities; IUPSWA) in the form of water tourism, accommodation, transportation, and adventure tourism. Information related to the performance of sustainable nature tourism management obtained in this study is expected to be a reference for other nature tourism managers in developing the potential for sustainable ecotourism, which has never been done before.

\section{Methods}

This study adopts the basic concept of evaluating the management of natural tourism as stipulated in the Regulation of the Ministry of Tourism Number 14 of 2016 on Guidelines for Sustainable Tourism Destination. This regulation is aligned with the indicators developed by the United Nations World Tourism Organization (UNWTO) and has been recognized by the Global Sustainable Tourism Council/GSTC. The principles of sustainable ecotourism developed by UNEP (2002) were also employed as a critical point in the analysis.

The regulation covers four general scopes that guideline the success of sustainable ecotourism: (1) management, (2) economic benefits to local communities, (3) cultural preservation for both the local community and visitors, and (4) environmental conservation. Compliance for each aspect of the four scopes is elaborated by using empirical evidence and descriptive analysis. The data were collected under three main techniques: a direct interview with related stakeholders, field measurement and direct observation, and grey literature. Quantitative data were obtained from information based on the results of the questionnaire for visitors who already enjoyed environmental services in the park, with a total of 97 respondents. Determination of the respondents using accidental sampling technique, and the results were then processed with simple statistics.

Aspects of each scope and type of taken data used in this study for each scope are described as follows:

(1) Management of effective sustainable tourism destination: The scope of "management of effective sustainable tourism destination" covers the management aspect that consisted of planning, organizing, controlling, and evaluation. In detail, this scope requires fulfillment of several criteria, i.e., Sustainable Destination Strategy, Destination Management Organization, Monitoring and Management Improvement Strategy, Inventory of Tourism Assets and Attractions, Visitor Satisfaction, and Promotion Destination.

(2) The optimization of economic benefits for local communities: This scope covers efforts required for a local career opportunity, supporting local entrepreneurs and fair trade, and tourism awareness and education.

(3) The optimization of cultural preservation for the communities and visitors: This scope underlines criteria that point to attraction protection, visitor management, and site interpretation.

(4) Environmental conservation: This scope covers aspects of protection for sensitive environments and Wildlife Preservation. 


\section{Results and Discussion}

TWA TWTP characteristics and management history Taman Wisata Alam Telogo Warno Telogo Pengilon is a conservation area that is also one of the attractions in the Dieng Plateau tourist destination, Wonosobo Regency, Central Java. This plateau has several other tourist objects, e.g., the Arjuna Temple Complex, Sikidang Crater, Lake Cebong, Sikunir Hill, Dieng View Post, and others.

In the reform era, the TWA TWTP suffered massive ecosystem damage. Balai Konservasi Sumber Daya Alam Jawa Tengah then succeeded in carrying out rehabilitation with native plant species in the area. Taman Wisata Alam Telogo Warno Telogo Pengilon area has an area of 35,905 ha (Forestry Minister Decree Number 3626/MenhutVII/KUH/2014 dated May 6, 2014, concerning the Establishment of the TWA TWTP), which is divided into Protection Block (16,129 ha), Rehabilitation Block (6,634 ha) and Utilization Block (13,141 ha). PT. AIBBL obtained an IUPSWA for a 55 years concession in the Utilization Block (covering an area of 6,023 ha) and started the operational on June 5, 2018.

Telogo Warno is a lake with a high sulfur content that makes the water looks colorful, while the Telogo Pengilon is a freshwater lake whose surface is bright as a mirror. The color is a reflection of sunlight reflected by sediments or rocks at the bottom of a lake, which in ancient times was a volcanic crater (Soeprobowati et al., 2016). The red and yellow colors are reflections of sulfur deposition elements; the white color comes from the deposition of limestone and quartz. The water quality of the two ponds is very different, especially from the parameters of $\mathrm{pH}$ and electrical conductivity (which is an indicator of dissolved solids). Telogo Warno water is acidic (low $\mathrm{pH}$ ), with high electrical conductivity, whereas Telogo Pengilon shows chemical properties with lower electrical conductivity (Sudarmadji et al., 2015). Uniquely, even though it is located side by side, water from each lake do not affect each other; Telogo Pengilon water remains fresh and is not mixed with sulfur. This condition is due to the two lakes being separated by land 2-5 m wide in between.

This uniqueness makes TWA TWTP one of the tourism icons in the Dieng Plateau, next to the Arjuna Temple Complex and Sikidang Crater, even a leading tourism attraction in Wonosobo Regency.. Another attraction of TWA TWTP is that some caves are used as hermitage and beautiful landscape views from the heights.

Current management efforts in TWA TWTP Some management efforts that have been made at TWA TWTP to date and have been captured by researchers are described as follows:

Management of effective sustainable tourism destination Sustainable destination strategy Specific TWA TWTP development strategies are outlined in the form of a Management Plan described in Rencana Pengelolaan (RP) document concerning the 2015-2019 Directorate General of Natural Resources and Ecosystem Conservation Strategic Plans (Directorate General of Conservation of Natural Resources and Ecosystems,
2015). In the RP mentioned that TWA TWTP management is a form of management that can guarantee the sustainability of the functions of protection, preservation, and utilization based on the principle of sustainability, and also able to provide optimal benefits for the community. This vision is in line with the concept of sustainable tourism (Kiper, 2003). The strategies related to the operational provision of nature tourism facilities are compiled in the Five Year Work Plan Book (Rencana Karya Lima Tahun, RKL) 2018-2023, and the Annual Work Plan I (Rencana Karya Tahunan, RKT) (2018-2019).

In addition to the RP and RKL-RKT, the other primary plan documents, namely the Central Java Regional Spatial Plan (Rencana Tata Ruang Wilayah/RTRW Provinsi Jawa Tengah) 2009-2029, have established TWA TWTP as part of the nature preservation area that must be protected. The Wonosobo District RTRW 2010-2019 document stipulates that the use of TWA TWTP must be carried out by taking into account the TWA TWTP function as an area of environmental preservation and protection of biodiversity of biota and ecosystems. The management strategy has accommodated aspects of ecosystem sustainability assurance in TWA TWTP (Rosalino \& Grilo, 2011), e.g., defining block arrangement map, planting trees on a rehabilitation block, and aspects of the local community interests (Kline, 2001). Including in the local community interest is aspects of economic value utilization that will be accepted by local communities (Honey, 1999).

Destination management organization The Technical Implementation Unit (Unit Pelaksana Teknis/UPT) of Natural Resource Conservation (KSDA) is a management unit of natural resource conservation and its ecosystem which is under and is responsible to the Director-General of Conservation of Natural Resources and Ecosystems, Ministry of Environment and Forestry (KLHK) based on Regulation of the Minister of Environment and Forestry Number P.8/MENLHK/Setjen/OTL.0/1/2016 concerning the Organization and Work Procedure of the Technical Implementation Unit for Conservation of Natural Resources. The UPT KSDA has the task of organizing the conservation of natural resources and their ecosystems in nature reserves, wildlife reserves, natural tourism parks, and hunting parks, as well as coordinating technical management of major forest parks and essential ecosystem areas. In the implementation of ecotourism activities, the UPT KSDA has limitations, both in terms of authority, budget, and human resources, to carry out the utilization of the natural tourism optimally.

Therefore, the government makes a partnership effort by providing opportunities for individuals, business entities, and cooperatives in the management of nature tourism as a form of community empowerment (Chaperon, 2017). In this context, the government acts more as a director than an executive (Osborne \& Gaebler, 1991). In TWA TWTP, the implementation of 
management in the operational level is given to the private sector (PT. AIBBL) following Government Regulation Number 36/2010 concerning Exploitation of Nature Tourism in Wildlife Reserves, National Parks, Grand Forest Parks, and Nature Recreation Parks in the form of granting IUPSWA.

Monitoring and management improvement strategy Management of TWA TWTP has carried out periodic monitoring and evaluation efforts. The monitoring and evaluation instrument used is the Management Effectiveness Tracking Tools (METT) following Regulation of the Director-General of Conservation of Natural Resources and Ecosystem Number P.15/KSDAE-SET/2015 dated 4 November 2015 concerning Guidelines for Assessing the Effectiveness of Conservation Area Management in Indonesia. The high METT value reflects management has been following the designation of the function of the area. In the area of natural tourism parks, the highest degree of management can be reflected by the region's contribution to the welfare of the community, nation, and state, both tangible and intangible. The concept of sustainable tourism underlines not only the economic benefits (Honey, 1999) but also aspects of the preservation of the ecosystem of natural tourism locations (Rosalino \& Grilo, 2011), the interests of local communities (Kline, 2001), and education for visitors (Balmford et al., 2009). The higher the METT score, indicates that the managed conservation area has been significantly intervened to solve the problems that surround it, so that the community can get tangible benefits, both directly and indirectly. There is a definite management improvement in TWA TWTP, indicated from significant increase achieved in a very short of a period (54 in 2016, increased to 76 in 2018).

Inventory of tourism assets and attractions The TWA TWTP manager has carried out the inventory assets. Some of the natural tourist spots in the TWA TWTP area which get a lot of visitors' attention are Telogo Warno, Telogo Pengilon, Sikendang Crater, Gua Jaran, Gua Sumur, Gua Semar, Pesanggrahan Batu Belik Cundamanik, and Batu Tulis. Some of these tourist spots in the TWA TWTP area have very strong local cultural content. For example, a small pool in the Gua Sumur has very clear and cold water. The water in the pool, named Tirta Perwitasari, is believed to cure various types of diseases and also make the skin clean. In addition, Tirta Perwitasari water is also often used by Hindus from Bali for Muspe or Mabakti ceremonies. The trust of the local community is one of the attractions of the tourist spot and is a reflection of the local content that characterizes the TWA TWTP tourism area.

Visitor satisfaction In general, visitors imply a high degree of satisfaction with the potential offered by TWA TWTP. Although there are a variety of other tourist spots in Dieng Plateau (e.g., Arjuna Temple Complex, Bukit Sikunir, Gatot Kaca Temple, Sikidang Crater, and Merdada Lake, as well as a variety of other playground tourist spots), as many as $56 \%$ of visitors considered TWA
TWTP as the main tourist destination. As many as 54\% of them admit that TWA TWTP is the most attractive tourist attraction. Most (66\%) of respondents stated that the most preferred part of TWA TWTP was its natural scenery, then the unique character of the lake $(19 \%)$, followed by the freshness of the air (14\%). However, not all visitors who have a high interest in TWA TWTP visit TWA TWTP. This is because they are members of a tourist/tour group, so these potential visitors have limitations in their movement space. The perception that was captured indicates that the landscape of this tourist area attracts visitors to come and enjoy its beauty.

Promotion destination Individual travel agents and promotions mostly do specific promotions that address TWA TWTP as a tourism destination. Managers of TWA TWTP, namely BKSDA and PT. AIBBL did not make many promotional efforts. Media that is widely used in promotion is online media (including social media). A search on the Google search engine with the code "Telogo Warno Telogo Pengilon" gives the results of the search engine result page (SERP) as much as 44,200, meaning that there are 44,200 blogs or websites that use Telogo Warno and Telogo Pengilon as keywords. A search with the keyword of Telaga Warna Dieng gives a higher result (which is 144,000 pages). Although this number is still very small compared to other nature tourism area keywords (such as Danau Toba with 9,210,000 pages), the page explaining TWA TWTP is relatively more efficient compared to several other TWAs within the Central Java BKSDA management area (i.e., TWA Guci with 79,300 pages or TWA Sumber Semen Rembang with 101,000 pages).

A survey of visitors shows that $42 \%$ of visitors know TWA TWTP information from online media, and $47 \%$ get information from friends/family/school or other sources they believe. Promotion information received by visitors is accepted as favorable information, which is indicated by the large percentage of the visitor who decides to visit TWA TWTP of their own decision. As many as $66 \%$ of respondents visited TWA TWTP of their own volition, not invited or because of work demands. This promotion is also quite useful in reaching potential visitors from various locations. This is indicated from the results of a

Table 1 The number of TWA TWTP visitors in 2012-2018

\begin{tabular}{lc}
\hline Year & Number of visitors (people) \\
\hline 2012 & 155,516 \\
2013 & 210,372 \\
2014 & 345,393 \\
2015 & 388,521 \\
2016 & 376,354 \\
2017 & 289,867 \\
2018 & 416,259 \\
\hline Total & $2,182,282$ \\
\hline Average & 311,754 \\
\hline
\end{tabular}


Table 2 The number of domestic and foreign visitors at TWA TWTP in June-December 2017 and 2018

\begin{tabular}{llrr}
\hline \multirow{2}{*}{ Month } & \multicolumn{1}{c}{ Visitor origin } & \multicolumn{2}{c}{ Year } \\
\cline { 3 - 4 } June & Domestic & 36,031 & \multicolumn{1}{c}{2018} \\
& Foreign visitor & 36 & 76,630 \\
& Domestic & 34,024 & 51 \\
\hline July & Foreign visitor & 107 & 52,100 \\
& Domestic & 15,653 & 175 \\
\hline August & Foreign visitor & 130 & 44,835 \\
& Domestic & 15,833 & 344 \\
\hline September & Foreign visitor & 122 & 35,510 \\
& Domestic & 13,600 & 156 \\
\hline October & Foreign visitor & 60 & 24,749 \\
& Domestic & 9,194 & 84 \\
\hline November & Foreign visitor & 27 & 25,438 \\
& Domestic & 37,446 & 56 \\
\hline December & Foreign visitor & 31 & 58,556 \\
& & 162,294 & 418,730 \\
\hline Total & & & \\
\hline
\end{tabular}

survey of visitors ( $\mathrm{n}=97$ respondents), which showed that domestic visitors came from 46 cities spread across 11 provinces. The nearest home city of visitors is Wonosobo-Central Java Province, while the farthest is Banda Aceh-Nanggroe Aceh Darussalam Province. Promotion performance was also reflected in visitor data, which showed a significant increase, from 155,516 visitors in 2012 to 416,259 visitors in 2018 (Table 1). The origin of the visitors is not only domestic but also foreign tourists. Although the percentage is still very low, the trend shows a consistent increase (Table 2).

However, it should be underlined that this promotional effort was carried out, not by the TWA TWTP managers. Therefore, the management of TWA TWTP needs to actively participate in disseminating promotion to the broader community and becoming a source of information that can be "trusted" by potential visitors, given the "trust" aspect is one of the critical aspects that provide the impetus for decision making as expected (Hajli, 2013). Hajli shows that the social interaction of individuals influences consumer attitudes towards a product or service. Networking on social media sites supports trust-building mechanisms in ecommerce and may encourage consumers to come online and use social media to develop trust.

The optimization of economic benefits for local communities Ten local community members are officially involved in TWA TWTP tourism area management activities that work in the cleaning, ticketing, and culinary stewards section (BKSDA, 2019). This number needs to be increased, considering the involvement of local communities in the exploitation of natural tourism areas is one of the critical criteria in the concept of sustainable tourism development. In addition, the participation of local communities in the context of the protection of the preservation of the TWA TWTP tourism area is still not apparent. Managers need to provide more appropriate educational efforts, e.g., making interpretation 3both in the form of paving, cast concrete, or soil, which can be used by visitors to surround this tourist area. Various supporting facilities to provide comfort for visitors have also been built (Figure 1). Most respondents (54 people or $56 \%$ ) spend time in enjoying TWA TWTP for $1-2$ hours. The second most duration is 2 to 4 hours, which is 26 respondents. The visitor circulation pattern (Figure 2) shows that the farther the point of tourist attraction in the TWA TWTP area, the fewer visitors come/pass through it. Visitors tend to stop at specific points and then return to the previous direction. This might be caused by several reasons, partly because there was no clear information in the field about the detour or because visitors were tired of continuing the visit by walking around the area.

Site interpretation In 2004 the Central Java Provincial Government built the Dieng Plateau Theater building. Inside this building, visitors can watch documentary films about the history and myths related to Telogo Warno Telogo Pengilon. This theater also presents a documentary about the natural disaster of Sinila Crater. Interpretation boards in TWA TWTP have also been made since 2013, but repairs need to be done on several boards due to damage caused by the weather and some visitors' improper behavior.

The optimization of cultural preservation for the communities and visitors Protected animal species (Regulation of the Minister of Environment and Forestry of the Republic of Indonesia Number P.106/Menlhk/Setjen/Kum.1/12/2018 concerning Protected Plant and Animal Species) found in TWA TWTP is black eagle (local name: elang hitam; Ictinaetus malayensis), and river kingfisher (local name: raja udang; family Alcedinidae). Although the population is still a lot, black eagle spreads only in forested areas. The fact that the reproduction rate is very low (one egg per year), hunting, and habitat destruction causes the black eagle to be included as a protected animal. River kingfisher is a bird with a beautiful bright blue feather 

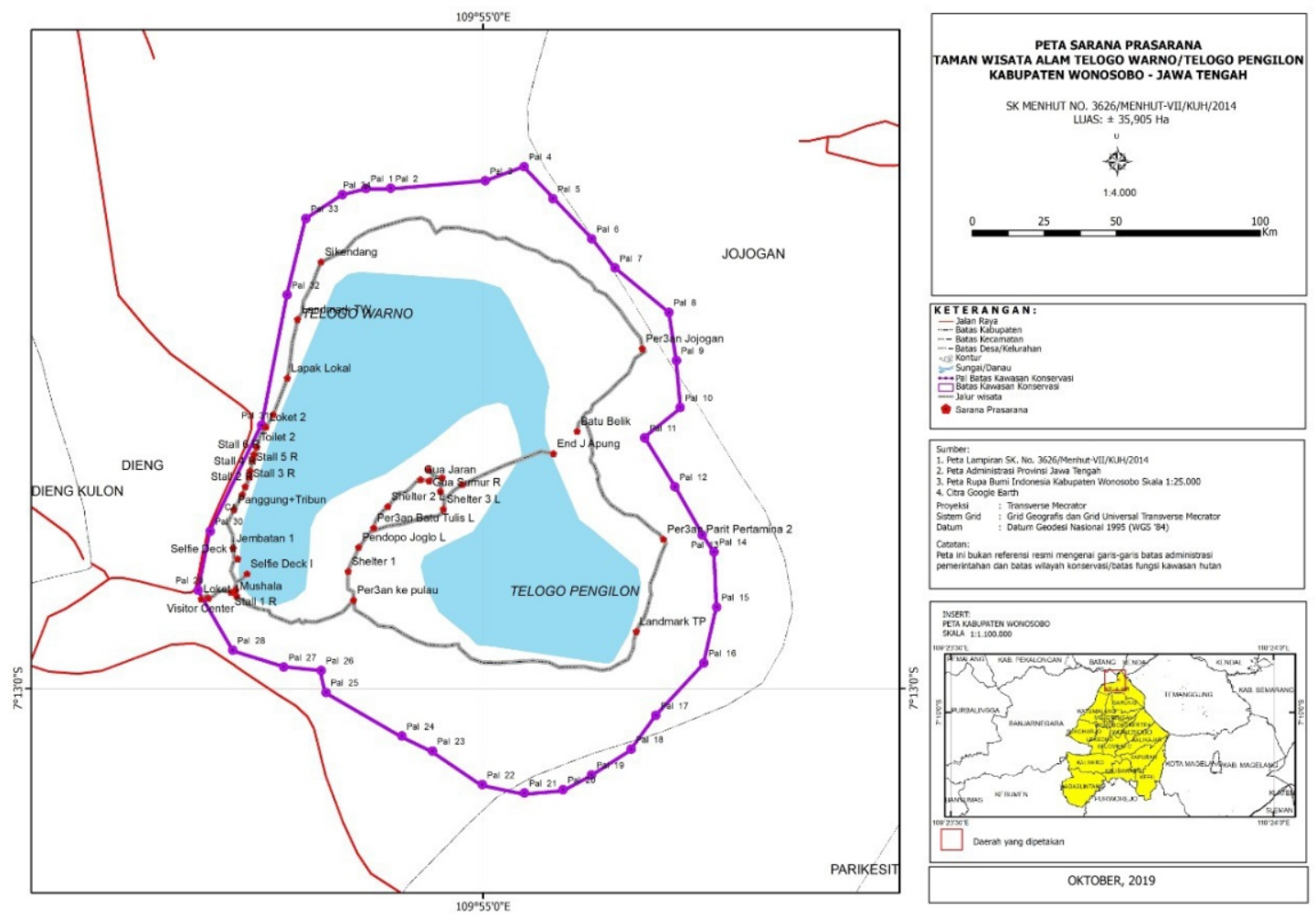

Figure 1 Map of the distribution of supporting facilities at TWA TWTP.

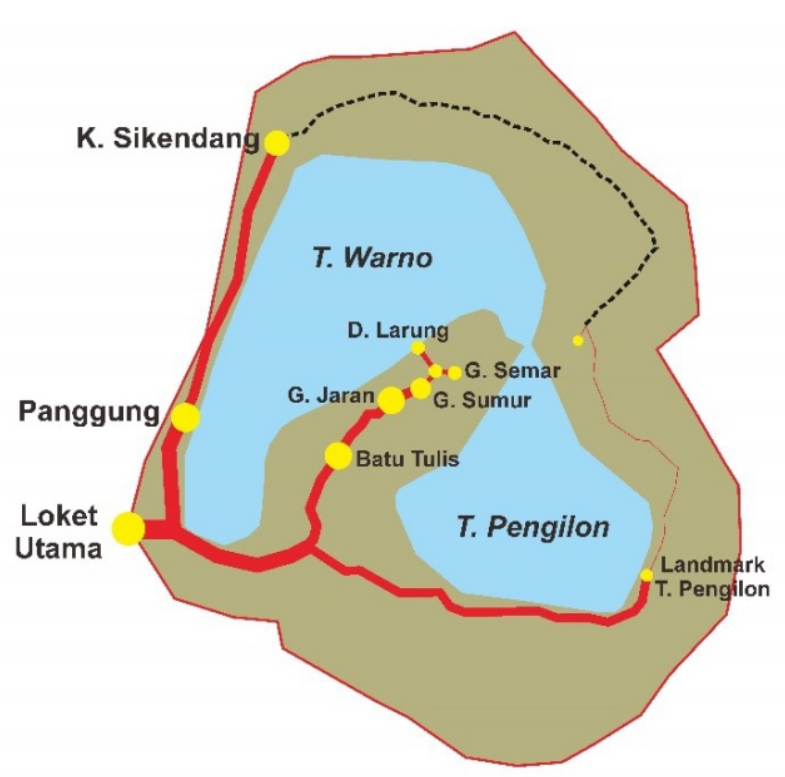

Figure 2 Circulation patterns of visits in TWA TWTP.

color that is aquatic. Telogo Pengilon, located next to Telogo Warno, provides food for river kingfishers.

In TWA TWTP, visitors can also find three other endangered species, i.e., kepodang (Oriolus chinensis; this bird is the icon of Central Java Province, pacific black duck (local name: mliwis; Anas superciliosa), and mandar batu (Gallinulla chloropus). Pacific black duck is a large water bird $(55 \mathrm{~cm})$, dark brown, foraging on the surface of shallow water, diving, and on land (Figure 3). These ducks are easy to recognize from a black stripe on the head. While flying, the white lower wings look very contrasted with the darker body feather. This bird spreads across Sumatra, Java to Australia and Polynesia, commonly found in lakes and overgrown swamps (MacKinnon et al., 1992). In TWA TWTP, this flock of water birds (5-12 depending on the season) permanently inhabit Telogo Warno, for nesting, resting at night, looking for food, and laying eggs. This water bird is sensitive to the presence of the human. When the visitors approach the edge of Telogo Warno, this flock of birds will swim away or fly to other lakes in the Dieng Plateau region. Although there is no report on disturbance from the visitor nor the local villagers, the management should give the educational aspect by placing information/ warning board about this flock.

Issues that should be addressed The performance of the TWA TWTP tourism area management, as described above, shows the positive efforts that have been carried out with positive results. However, there are still some things that need improvement. These aspects are described as follows:

Management of effective sustainable tourism destinations In the scope of the management of effective sustainable tourism destinations, the management of TWA TWTP still has not accommodated the individual needs of people with disabilities, especially in the form of special trail equipped with tactile paving to assist visitors 


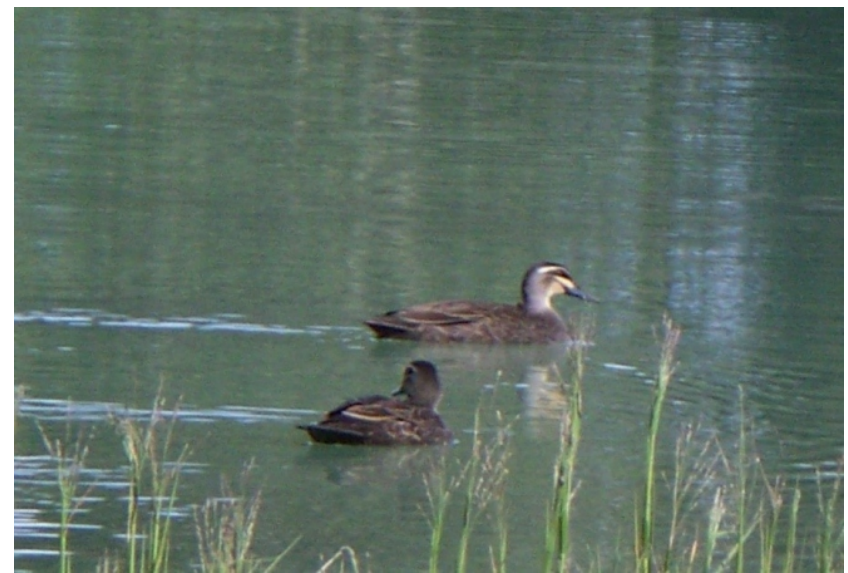

Figure 3 Pacific black ducks (Anas superciliosa) that can be found in TWATWTP.

with visual impairment or those who use wheelchair/pushchair.

Furthermore, TWA TWTP has a natural source of danger that is difficult to control. Therefore the principle of hazard control that needs to be applied is by providing information and warning signs that can be read and understood by visitors. Information that needs to be conveyed includes types of hazardous sources, hazards, possible risks, and procedures for emergencies. The warnings that need to be delivered are safe distance and duration of exposure.

In addition, terms of visitor security facilities have also not been optimally considered. The aid kit available is the first aid kit and wheelchair only. Warning signs are still lacking, whereas, in the TWA area, there is Sikendang Crater, which releases volcanic gases such as carbon dioxide $\left(\mathrm{CO}_{2}\right)$ and hydrogen sulfide $\left(\mathrm{H}_{2} \mathrm{~S}\right)$. Sikendang Crater has a very high $\mathrm{CO}_{2}$ concentration (reaching $73.801 \%$ by volume) and $\mathrm{H}_{2} \mathrm{~S}$ content (reaching $5.196 \%$ by volume) (Priatna, 2014). High concentrations of $\mathrm{CO}_{2}$ gas, colorless, and odorless can be dangerous, while the presence of $\mathrm{H}_{2} \mathrm{~S}$ gas is indicated by the smell of rotten eggs that are very pungent. Both of these gases can trigger nausea and dizziness when exposed for a long time. In extreme cases, the accumulation of $\mathrm{H}_{2} \mathrm{~S}$ and $\mathrm{CO}_{2}$ from volcanic and geothermal sources can cause death from shortness of breath (Hansell \& Oppenheimer, 2005). Chronic exposure to $\mathrm{H}_{2} \mathrm{~S}$ in geothermal areas is also associated with an increase in diseases related to the nervous and respiratory systems.

Another shortcoming that needs to be underlined is the absence of a mechanism governing the management of the emergency response in the control documents (the Rencana Pengelolaan and Rencana Karya Lima Tahun). Included in the meaning of "emergency response" is the planning of resources (humans, facilities, and funds) that need proper emergency response actions. Further, several points that needs to be underlined are (1) the absence of a mechanism governing the management of the emergency response and (2) proper program to improve the competence of human (refers to both managements, workers, local community members, and visitors), facilities, and funds required to carry out the proper emergency response actions. The competence issue should be seriously underlined, especially when it pointed to the aspect of safety and health protection, as stated by Yovi and Yamada (2019) and Yovi (2019). The Indonesian forest industry, including ecotourism, faces a severe problem when it comes to these three aspects. As a decision-maker, the government should take the lead to overcome this issue. Any certification or evaluation instrument that is used in this industry should be constructed appropriately, meaning that the assessment instrument must be adjusted to the measured dimension. Therefore, when it should be a performance-based assessment, the administrative-based evaluation instrument would never work (Yovi \& Nurrochmat, 2018).

The optimization of economic benefits for local communities In this scope, current management needs to carry out direct monitoring and regular data collection efforts in the form of visitor, labor, and investment expenses. The data is essential to find out how the current ecotourism has benefited the local community in terms of household economies, employment, and cash income (Liu, 2003). Another aspect that needs attention is the participation of the local community. Local community participation is indispensable in ecotourism destination development (Sebola \& Fourie, 2006), especially if they have a direct link in the social, cultural, and economic context of ecotourism activities, for example, allowing them to open culinary stall and selling local homemade souvenirs.

Local communities also need to be included in an official forum consisting of elements of BKSDA, the Wonosobo Regency Tourism Service, and local communities. This way, local community participation actions can accommodate the needs of the local community and the development of ecotourism destinations. The forum meeting should be held regularly to discuss various issues related to destination management. In these forums, managers can collect, monitor, and record and report related to the aspirations, concerns, and satisfaction of the local community with destination management. This forum can also bridge the management to understand the actual needs of the local community so that ecotourism activities can indeed provide tangible benefits for the local community (Mensah \& Ernest, 2013).

The optimization of cultural preservation for the communities and visitors The superiority in TWA TWTP is the Telogo Warno and Telogo Pengilon. The fact that TWA TWTP is in the middle of local community agricultural land is something to be aware of as one form of threat to the TWA TWTP ecosystem. For example, during the rainy season, the massive opening of the area causes the rate of rainwater infiltration to be lower than the runoff rate, which will lead to overland flow (Guzha et al., 2018). Since the locations of Telogo Warno and Telogo Pengilon are located in the lower area of these 
agricultural land, the water that brings sediment flows to the two lakes, causing the lakes to turn to muddy and shallow (Zhang et al., 2010). In the dry season, lake water recedes due to the extensive use of water by local farmers to water their agricultural land. Efforts to minimize this often irreversible impact need to be formulated by continuing to include the local community as key stakeholders in the context of managing sustainable tourism development in TWA TWTP.

Environmental conservation Efforts made by managers to increase the number of visitors should be executed by considering the carrying capacity of the area to accommodate the number of tourists who come at a specific period. The problem found in TWA TWTP is the relatively high PNBP target set by the Central Government. At the implementation level, this target is then interpreted as an effort to bring as many visitors as possible. The number of visitors can negatively affect the environmental quality of the area. Ecosystem balance consisting of biotic and abiotic components can be disrupted due to noise pollution, air pollution, and pollution of visitors' meal waste. Another element that can also be disturbed is the social and cultural aspects of the local community (Anup, 2016).

An alternative solution to bridge the demands of the preservation of the ecological functions of the region and the PNBP targets are by limiting the number of visitors according to the area's carrying capacity (CC) (Kotler et al., 2002). Even though there will be a small number of visitors, but the activity is carried out as an exclusive program. This way, high financial income can still be achieved. This concept is following the definition of ecotourism stated by Ceballos-Lascuráin (1996), that ecotourism is a tourist trip to relatively undisturbed natural places, to study, admire, and to enjoy the scenery, plants, animals, and cultural aspects (both past or present) found in these places.

Carrying capacity should be used as the primary reference in setting the number of visitors. This is due to the concept of sustainable ecotourism. Tourism planners need to take into account the environmental capacity of a location to be able to support all elements involved in ecotourism activities. Without proper planning, a tourist destination can suffer damage to the environment, the social and local culture, which can be irreversible (Anup, 2016).

From a marketing point of view, sustainable tourism can mean giving up income from current tourism by limiting the capacity to ensure that there will be demand for trips in the future. For managers of attractions, efforts to focus on sustainable and responsible tourism need attention. Therefore, referring to research in Germany, managers of tourist destinations are no longer only responsible for marketing matters but also the preservation of their natural resources (Estrella et al., 2019).

\section{Conclusion}

Management at TWA TWTP still shows the need for improvement in the four scopes to guarantee TWA TWTP sustainability as a natural tourism destination. Improvements are needed in the scope of management of effective sustainable tourism destinations, including the individual needs of people with disabilities and visitor security facilities, and emergency responses. In terms of optimization of economic benefits for local communities, current management needs to carry out direct monitoring and regular data collection efforts, in the form of visitors, labor, and investment expenses. In addition, increasing the level of local community participation also should be seriously addressed because, in the TWA TWTP case, the local community has a direct link in the social, cultural, and economic context of ecotourism activities. Cultural preservation for the communities and visitors should also be taken as the primary issue in the immediate improvement. The fact that there is a massive land opening due to intensive agriculture surrounding TWA TWTP should be considered as a serious threat. The impact is often irreversible. Preventive actions needed to be formulated while also accommodating the local community needs and participation as key stakeholders. Finally, there is a need to consider the number of visitors allowed, which is calculated according to the carrying capacity of TWA TWTP. The NonTax State Revenue (PNBP) targets also should be recalculated by considering the TWA TWTP carrying capacity factor.

\section{References}

Anup, K. C. (2016). Ecotourism and its role in sustainable development of Nepal. In L. Butowski, Tourism-From Empirical Research Towards Practical Application. IntechOpen. https://doi.org/10.5772/62308

Balmford, A., Beresford, J., Green, J., Naidoo, R., Walpole, M., \& Manica, A. (2009). A global perspective on trends in nature-based tourism. PLoS Biol, 7(6), e1000144. https://doi.org/10.1371/journal.pbio.1000144

[BKSDA] Balai Konservasi Sumber Daya Alam Jawa Tengah. (2019). Laporan monitoring dan evaluasi ijin usaha penyediaan sarana wisata alam TWA Telogo Warno Telogo Pengilon. Semarang: Balai Konservasi Sumber Daya Alam Jawa Tengah.

Blamey, R. K. (2001). Principles of ecoutourism. In D. B. Weaver, The ecyclopedia of ecotourism. CABI Publishing. Retrieved from http://shora.tabriz.ir/ Uploads/83/cms/user/File/657/E_Book/Tourism/The Encyclopedia of Ecotourism.pdf\#page=19) 25 November 2019. Pp 5-22.

[BPS] Biro Pusat Statistik. (2019). Statistik wisatawan nusantara 2018. Jakarta: Biro Pusat Statistik Republik Indonesia.

Ceballos-Lascuráin, H. (1996). Tourism, ecotourism and protected areas. Switzerland and Cambridge: IUCN Gland.

Chaperon, S. (2017). Tourism industry responses to publicprivate partnership arrangements for destination 
management organisations in small island economies: A case study of Jersey, Channel Islands. International Journal of Tourism Policy, 7(1). https://doi.org/10.1504/ IJTP.2017.10003750

Das, M., \& Chatterjee, B. (2015). Ecotourism: A panacea or a predicament? Tourism Management Perspecttive, 14, 3-16. https://doi.org/10.1016/j.tmp.2015.01.002

Directorate General of Conservation of Natural Resources and Ecosystems. (2015). Rencana Strategis Direktorat Jenderal Konservasi Sumber Daya Alam dan Ekosistem Tahun 2015-2019. Jakarta: Direktorat Jenderal Konservasi Sumber Daya Alam dan Ekosistem, Kementerian Lingkungan Hidup dan Kehutanan.

Estrella, G., Zemp, M., \& Wagenseil, U. (2019). Corporate social responsibility: The role of modern destination management organizations. BEST EN Think Tank XVI Corporate Responsibility in Tourism-Standards Practices and Policies.

Fandeli, C., Muhammad. (2019). Analisis daya dukung lingkungan dalam perspektif pembangunan berkelanjutan. Jakarta.: Direktorat Jenderal Konservasi Sumber Daya Alam dan Ekosistem, Kementerian Lingkungan Hidup dan Kehutanan.

Gössling, S. (1999). Ecotourism: A means to safeguard biodiversity and ecosystem functions? Ecological Economics 29, 303-320.

Guzha, A. C., Rufino, M. C., Okoth, S., Jacobs, S., \& Nóbrega, R. L. B. (2018). Impacts of land use and land cover change on surface runoff, discharge and flows: Evidence from East Africa. Journal of Hydrology: Regional Studies, 15, 49-67.

Hajli, M. N. (2013). A study of the impact of social media on consumers. International Journal of Market Research, $5(3)$.

Hansell, A., \& Oppenheimer, C. (2005). Health hazards from volcanic gases: A systematic literature review. Archives of Environmental Health: An International Journal, 59(12), 628-639 https://doi.org/10.1080/0003989040 9602947

Hetzer, W. (1965). Environment, tourism, culture. Links, $1-3$

Honey, M. (1999). Ecotourism and sustainable development: Who owns paradise? Washington, DC: Island Press.

Kline, J. D. (2001). Tourism and natural eesource management: A general overview of research and issues. Gen. Tech. Rep. PNW-GTR-506. Portland: U.S. Department of Agriculture, Forest Service, Pacific Northwest Research Station. https://doi.org/10.2737/ PNW-GTR-506

Kiper, T. (2013). Role of ecotoursm in sustainable development. In M. Ozyavuz, Advance in Ladscape Architecture. IntechOpen. https://doi.org/10.5772/55749

Kotler, P., Bowen, J., \& Makens, J. (2002). Marketing for hospitality and tourism ( $3^{\text {rd }}$ ed.). New Jersey: Pearson Education.

Lepetu, J., Makopondo, R. O. B., \& Darkoh, M. B. K. (2008). Community-based natural resource management and tourism partnership in Botswana: Which way forward? Botswana Notes and Records, 39, 113-124.

Liu, Z. (2003). Sustainable tourism development: A critique. Journal of Sustainable Tourism, 11(6), 459-475. https://doi.org/10.1080/09669580308667216

MacKinnon, J., Phillipps, K., \& van Balen, B. (1990). Buku panduan lapangan pengenalan burung di Sumatera, Jawa, Bali dan Kalimantan. Yogyakarta: Gajah Mada University Press.

Mensah, I., Ernest, A. (2013). Community participation in ecotourism: The case of Bobiri Forest Reserve and Butterfly Sanctuary in Ashanti Region of Ghana. American Journal of Tourism Management, 2(1A), 34-42 https://10.5923/s.tourism.201304.04

Mollet, J. A. (2016). Sustainable development ecotourism in West Papua: Learning from the Scottish experience. Paper presented at ICSBP Conference Proceeding. https://doi.org/10.18502/kss.v1i1.429

Osborne, D., \& Gaebler, T. (1991). Mewirausahakan birokrasi. Jakarta: Pustaka Binaman Pressindo.

Priatna. (2014). Karakteristik gas vulkanik dan implikasinya terhadap daerah wisata di dataran tinggi Dieng. Jurnal Lingkungan dan Bencana Geologi, 5(3), 159-172.

Rosalino, L. M., \& Grilo, C. (2011). What drives visitors to protected areas in Portugal: accebilities, human pressure or natural resources? Journal of Tourism and Sustainability, 1(1), 2-11.

Sebola, M. P., Fourie, L. de W. (2006). Community participation in ecotourism destinations: Maleboho Nature Reserve. In C. A. Brebbia, \& F. D. Pineda, Sustainable tourism II. Southampton: WIT Press. https://doi.org/10.2495/ST060181

Soeprobowati, T. R., Suedy, S. W. A., \& Hadiyanto. (2016). Diatoms and water quality of Telaga Warna Dieng, Java Indonesia. Paper presented at 2nd International Conference on Tropical and Coastal Region Eco Development. IOP Publishing. IOP Conf. Series: Earth and Environmental Science, 55, 012-051. https://doi.org/ $10.1088 / 1755-1315 / 55 / 1 / 012051$

Sudarmadji, Supriyono, H., \& Lestari, S. (2015). Danaudanau vulkanik di Dataran Tinggi Dieng: Pemanfaatan dan masalah lingkungan yang dihadapi. Jurnal Teknosains, 5(1), 1-80. 
[TIES] The International Tourism Society. (2019). https://ecotourism.org/what-is-ecotourism

[UNEP] United Nations Environment Programme. (2002). Making tourism more sustainable: A guide for policy makers. Paris: United Nations Environment Programme.

[UNWTO] United Nation World Tourism Organization. (2018). UNWTO Annual Report 2017. Madrid: United Nations World Tourism Organization.

World Tourism Organization. (2018). UNWTO Annual Report 2017. United Nations World Tourism Organization. Madrid

Yovi, E. Y. (2019). Status ergonomi pekerja sektor kehutanan di Indonesia: Kelelahan fisik-mental-sosial, kepuasan kerja, konsep sumber bahaya, dan konsep biaya kecelakaan. Jurnal Ilmu Kehutanan, 40(2), 137-150. https://doi.org/10.22146/jik.52140

Yovi, E. Y., \& Yamada, Y. (2019). Addressing occupational ergonomics issues in Indonesian forestry: Laborer, operator, or equivalent workers. Croatian Journal of Forest Engineering, 40(2), 351-363. https://doi.org/ $10.5552 /$ crojfe. 2019.558

Yovi, E. Y., Nurrochmat, D. R. (2018). An occupational ergonomics in the Indonesian state mandatory sustainable forest management instrument: A review. Forest Policy and Economics, 91, 27-35. https://doi.org/ 10.1016/j.forpol.2017.11.007

Zhang, X., Cao, W., Guo, Q., \& Wu, S. (2010). Effect of landuse change on surface runoff and sedimen yield at different watershed scales on the Loess Plateau. International Journal of Sedimen Research 25(3), 283-293. https://doi.org/10.1016/S1001-6279(10) 60045-5. 4 .

Zhao, Y., Jiao, L. (2019). Resources development and tourism environmental carrying capacity of ecotourism industry in Pingdingshan City, China. Ecological Processes, 8:7. https://doi.org/10.1186/s13717-0190161-0 